\title{
COMPARISON OF ORDOVICIAN LITHISTID SPONGE COMMUNITIES IN THE GREAT BASIN
}

\author{
JOHNS*, Ronald A., Dept. of Geological Sciences, Univ. of Texas at Austin, Austin, TX 78713-7909
}

Lithistid sponges are an important component of many Ordovician faunas and form some of the earliest reef communities of the Paleozoic Evolutionary Fauna, yet they have received relatively little attention. Fossiliferous strata with abundant sponges occur at many horizons and localities within the Lower and Middle Ordovician Pogonip Group of the Great Basin. One of the best-known occurrences is near the middle of the Antelope Valley Limestone in central Nevada, where sponge-bearing units occur within the lower Whiterockian Stage. Lithistid sponges and associated species were also examined within the Shingle Limestone of eastern Nevada, where the sponge communities occur as small reef mounds about $55 \mathrm{~m}$ below the top of the formation in beds corresponding to the uppermost Ibexian Series. To acquire a more regional view of the environments and faunas present in Nevada during the Ordovician, contemporaneous units in the Pogonip Group were examined elsewhere in Nevada and in the Ibex area of western Utah.

The general depositional setting of the Great Basin at this time was that of a carbonate ramp in the upper Ibexian developing into a carbonate platform during the Whiterockian. The sponge mounds in the Shingle Limestone, forming in water 1 to $15 \mathrm{~m}$ deep, may have participated in this development by interfering with water circulation along the outer portion of the carbonate ramp. The mounds are several meters in size and are often stacked, with grainstone-filled channels cutting through the mounds in several places. The mounds themselves have muddy cores and are flanked by well-sorted echinoderm grainstones. The reef trend extends for nearly two kilometers before being faulted out, and was probably even more extensive during its development. Besides sponges, the assemblage contains abundant calcareous algae and cyanobacteria, as well as trilobites, brachiopods, echinoderms, and other groups characteristic of the Paleozoic Fauna. These mounds are very similar to those found in the Wahwah and Juab Limestones of the Pogonip Group, suggesting that these latter buildups also formed in very shallow water.

The younger sponge communities in the Antelope Valley Limestone at Ikes Canyon probably formed in about 20 to $40 \mathrm{~m}$ of water along the uppermost slope of a carbonate platform. The sediments consist of interbedded wackestones, mudstones, and shales with occasional hardgrounds. Some of the sponges have root tufts, indicating that they settled on soft substrate. Besides lithistid and heteractinid sponges, the unit contains a diverse assemblage of metazoans and occasional receptaculitids and other algae.

Estimates of relative species abundances were calculated for random samples from the sponge-bearing units. The Shannon Diversity Index for the Antelope Valley Limestone fauna is 3.24 with an equitability value of 0.68 , while the Shingle Limestone community has values of 3.44 and 0.74 , respectively. Thus, not only were both communities diverse, but the species within each community were comparable in abundance. These values compare favorably with those of modern marine communities, especially when the effects of preservational bias are considered, and suggest that well-integrated ecological communities with substantial amounts of biotic interaction had evolved by the Middle Ordovician.

The sponge communities of the Antelope Valley Limestone and Shingle Limestone are thus quite similar, yet only in the latter did the organisms build bioherms. The sucession of communities within these buildups indicate that the greater abundance of cyanobacteria and calcareous algae in the Shingle Limestone probably helped to bind and stabilize the sediment, creating a firm substrate. This was then settled by cylindrical and branching lithistid sponges and other species that not only acted as bafflers, causing mud to accumulate, but produced additional sediment when they died. As the mounds grew, the communities diversified, with cup-shaped lithistids becoming dominant as the bioherms approached sea level. The importance of calcareous algae and cyanobacteria in determining whether mud mounds developed in this depositional setting suggests that factors controlling the distribution of algae, primarily substrate, turbidity, and water depth, also control the distribution of mud mounds. This is probably true not only for these sponge mounds, but for mud mounds throughout the Paleozoic. 